\title{
Assessing the Need for PhD in Information Studies: Stakeholder Insights
}

\author{
Sajjadur Rehman*, Abdus Sattar Chaudhry, Hessah O. Alasousi \\ Division of Information Studies, Kuwait University, Kuwait City, Kuwait \\ Email: ^rehman05@gmail.com
}

How to cite this paper: Rehman, S., Chaudhry, A.S. and Alasousi, H.O. (2019) Assessing the Need for PhD in Information Studies: Stakeholder Insights. Open Access Library Journal, 6: e5322. https://doi.org/10.4236/oalib.1105322

Received: March 8, 2019

Accepted: April 12, 2019

Published: April 15, 2019

Copyright $\odot 2019$ by author(s) and Open Access Library Inc.

This work is licensed under the Creative Commons Attribution International License (CC BY 4.0).

http://creativecommons.org/licenses/by/4.0/

(c) (i) Open Access

\begin{abstract}
Seeking insights of stakeholders is an important element of the needs assessment process for starting a doctoral program. This paper reports a study that reviewed the perspectives of stakeholders with regard to a $\mathrm{PhD}$ in information studies. Feedback from major stakeholders was sought using a combination of qualitative and quantitative methods: a web-based survey of 180 relevant stakeholders (including current master students, alumni of the department, faculty members and working information professionals) followed by a focus group discussion with 7 faculty members from Kuwait University and Public Authority for Training and Education. Findings showed that there was a need for starting a $\mathrm{PhD}$ program in information studies at Kuwait University. Data also provided important insights about the structure of the proposed program, its content, areas of coursework and specializations. Results of the study might be useful for developing a $\mathrm{PhD}$ program in other universities. The findings are also expected to provide guidelines for conducting needs assessment for doctoral programs in information studies.
\end{abstract}

\section{Subject Areas}

Education, Information Science

\section{Keywords}

Information Studies Higher Education, Doctoral Programs, Stakeholder Insights, PhD Program Development

\section{Background}

Melville Dewey designed early tradition of library training programs in the academia of Columbia College and Albany School. Albany School awarded the first Master's degree in 1905 [1]. Subsequently several other universities started 
training programs and awarded varied degrees. Undergraduate degrees were later transformed into Master in library science until the 50s. Williamson Report provided an impetus to education programs in librarianship to be raised to the graduate level [2]. A number of universities offered Master's degrees, notably Columbia, Michigan, Illinois, California, Toronto and few others. This report was also instrumental in the development of $\mathrm{PhD}$ in the field of library and information science. It brought fundamental shift in LIS education moving it from vocational training to technical and subsequently professional education in academia spanning. Several authors have discussed the impact of these developments on the field of library and information science [1] [3] [4] [5].

Introduction and implementation of $\mathrm{PhD}$ at Chicago University in 1926 was a pioneering doctoral program in the field of LIS [3]. The Library Trends published an issue on LIS education in 1986 that provided details of the curriculum, content, and degree requirements of $\mathrm{PhD}$ programs. Doctoral studies have been instrumental in moving LIS to an academic and intellectual field of practice. An important conclusion emerging from these writings was that a shift to an academic context necessitated the development of doctoral studies in LIS. As mentioned in [3] Bobinski analyzed the evolution of doctoral studies at Chicago, Illinois, Michigan, Columbia, Case Western, and Berkley. Development of $\mathrm{PhD}$ programs continued for two decades of the 60s and the 70s. This is the era of boom in the award of $\mathrm{PhD}$ in US. In the 80s some reputable programs were closed down. Also, it was analyzed in [6] the demise of schools that were closed and [7] provided more details of these closings.

Despite the closing of several schools, growth of doctoral programs continued during the 80 s and the 90 s as reflected by statistics maintained by the Association of Library and Information Science Education (ALISE). These showed $\mathrm{PhD}$ enrollment in the range of 489 - 518 during 1979-84 in 23 - 24 doctorate awarding programs. Those who received doctorates ranged 11 - 40 during 1961-69 whereas during 1970-81, 64 - 135 were produced. The number of graduates exceeded 100 during 1973-80. Pittsburgh had a much larger share as it posted 56 dissertations during 1980-84. During this period a total of 345 doctorates were done in 24 schools. Interestingly, library science doctorates were 55\% in 1982 out of doctorates awarded in various fields in the US [3].

Recently iSchools have evolved as a general umbrella for the field of information, interacting with diverse disciplines. Most of the founders of the iSchool caucus were deans/directors of the former "library schools." These iSchools had distinctions of multi-disciplinarily, broad-based disciplinary orientation, and adoption of new types of coursework. These schools included the disciplines of library science, communication, computer science, and information systems [8]. This interdisciplinary nature of the area of information studies could be a challenge when developing a doctoral curriculum, as students and faculty come from many different backgrounds. A study was conducted in [9] about future trends for doctoral education in library and inforamtion science. They examined 
the hitorical progress and current landscape of doctoral degree programs in the United States and Canada. This study provided a comprehensive rendering of the history of LIS doctoral education.

$\mathrm{PhD}$ has been an integral part of LIS education during the last 90 years. Changes in the content and conduct have been noteworthy since iSchools have assumed new role and identity; making them more prominent, visible, and engaging. The demand for doctoral programs in the job market has generally been consistent. In [10] it was noted that about half of graduates apply research results to their professional work. Fleming-May \& Yuro found that academic librarians also had a role to assist doctoral students for the development of their research facilities such as databases and online catalogs [11]. Dominican University launched its first $\mathrm{PhD}$ program in library and information science as a professional degree for librarians in managing a balance between theory and practice. It was 3-year program with 36 credit hours and 2 years of coursework [12].

As described in [13] the state of doctoral education in LIS using a mentoring framework consists of four linear stages of initiation, cultivation, separation, and re-definition. This exploratory description is informative for producers and consumers of doctoral education. Bennett-Kapusniak [14] discussed a doctoral cohort program at the University of Wisconsin-Milwaukee that focused on educating the next generation of doctoral graduates in library and information science. Challenges in LIS doctoral education such as lack of financial support, exposure to research, mentoring, promotion of diversity were highlighted.

\section{Rationale}

The above review of professional literature indicated that role of doctoral studies was important in gaining maturity as an academic discipline in the field of library and information science. Role of doctoral programs was widely recognized and the number has been on the increase. With the expansion of scope of the LIS field to information studies further increased the growth of docotoral studies. In [15] [16] [17] [18] highlights were given to the potential of doctoral studies for academics, researchers and practitioners. The peculiarities of the field, however, need to be taken into consideration in making a decision to start a doctoral program. Field of information studies has a strong practical orientation in spite of meeting the critereia of an academic discipline. While the emergence of information studies opens more opportunities, interdisciplinarity and multi-disciplinary nature of the field brings more challenges for managing a doctoral program.

A well-thought out needs assessment is considered crucial before making decisions for starting a doctoral program in an information studies department. Understanding of insights of all stakeholders is an important element of this assessment and should include assessing market needs, developing detailed proposals, and converting proposals into programs of studies. This study was conceived with these considerations in view. Input from stakeholders provided pre- 
liminary data needed for peparing a proposal. Data on questions on the motives and the perceived challenges allowed valuable insights in the value of $\mathrm{PhD}$ in terms of its success, which can enhance the effectiveness of $\mathrm{PhD}$ programs. While the study was carried out in the context of a paticular university, the findings are expected to be useful for developing $\mathrm{PhD}$ program in other universities.

This study was conceived to seek opinions of stakeholders focusing on the following aspects:

- Values underlying the design of a $\mathrm{PhD}$ program

- Pedagogical considerations in developing a PhD proposal

- Specializations and curricula for the proposed $\mathrm{PhD}$ program

- Possible collaboration and inter-disciplinary initiatives for the success of $\mathrm{PhD}$ program

- Enrollment, graduation requirements, and incentives for graduates of the doctoral program

Data gathered in above areas indicated the value and need of doctoral program. Data were useful to examine the views and perceptions of stakeholders of a doctoral program in information studies. This information provides a step-by-step approach for needs assessment and development of a doctoral program in the field information studies.

\section{Methodology}

\subsection{Research Setting}

Locale for this research was Kuwait University. The university was established in 1966. A master's progamin library and information science was introduced at the College of Graduate Studies in 1996. This program was upgraded to an academic department, which was placed in the College of Social Science in 1998, Nomenclature for the master's degree was changed from library and information science to information studies in 2016. The name of the department was changed to that of Information Studies in 2017. More than 200 graduates have been produced by this department. They are working in different sectors in the country. A minor in information studies has also been available in the department for the last 10 years. The department has recently initiated a request to start a 4-year bachelor in information studies. Kuwait University is the only public university in the country. There are four private universities that run undergraduate and graduate programs in different major fields of studies. However, no other university is offering any program in the field of information studies. A 4-year bachelor's program in information studies is offered in the College of Basic Education of the Public Authority of Applied Education and Training (PAAET). Department of Information Studies at Kuwait University has been considering the possibility of starting a doctoral program in information studies. The study being reported in this paper was conducted about insights of skateholders so as to understand the implications of starting a $\mathrm{PhD}$ program. 


\subsection{Participants}

This study was conducted to seek feedback from major stakeholders of doctoral program. Major stakeholders included the current master students, alumni of the department, faculty members, and working information professionals. Professionals working in different Kuwaiti information organizations are the primary stakeholders who are expected to provide valuable and pertinent input about $\mathrm{PhD}$ studies at Kuwait University. It was realized that developing a viable proposal for Kuwait University required an assessment of the needs of job market and understanding of perceptions and views of stakeholders. A need was felt for conducting a comprehensive survey in order to gather views and insights of the stakeholders.

A list of potential participants was pepared by reviewing the list of alumni of the Department of Libray and Information Science. The list was expanded by adding working information professssionals identified from the various directories. Current master students were also added to this list. About 200 potential participants were identified but the list dropped to 180 as contact details could not be confirmed for 20 professioanls included in the list. Eventually, we approached 180 potential participants, out of whom 104 filled in the questionnaire. A cover letter was attached to the questionnaire that explained the purpose of the study in detail. The respondents included a wide range of executives, managers, professionals, and current master degree students, faculty members and other stakeholders in Kuwait. The selection of participants was essentially a convenience-based sample.

\subsection{Procedures}

The focus of this paper is on the survey focusing on seeking feedback from major stakeholders of doctoral studies at Kuwait University. Before conductinng the survey, a series of pre-survey steps were taken. A sub-committee of the Master Program Committee was appointed for developing a proposal for doctoral studies. The sub-committee consisted of three faculty members holding the academic rank of professor and associate professor. All faculty members hold $\mathrm{PhD}$ in information studies. The sub-committeee reviewed relevant documents particularly the guidelines for preparing proposal for graduate programs of the university. The sub-committee also collected information about faculty members' research and academic credentials, particularly about their areas of specialization so as to determine the availability of resources for teaching courses in the doctoral program.

A quesstionnaie was designed for the web-based survey. The questionnaire also sought feedback from participants about the job market and other implications of producing doctoral graduates. It contained 3 main sections:

- The first section contained an introduction where the main purpose of the study was given.

- The second section contained the demographic Data of the participants such 
as education, specialization, instituition affiliated with, age and experience.

- The third section contained 12 questions about needs assessment, curriculum design, and various features of the doctoral program.

All potential participants were invited through email to fill up the online questionnaire. They were also requested to forward the questionnaires to other information professionals who might be interested in the $\mathrm{PhD}$ program. Earlier response was not very encouraging. In line with the practice of survey-based studies, potential participants were reminded to fill-in the questionnaire, who might not have been able to spare time because of their professional and academic assignments. After a follow up was done through email messages and phone calls, the number of responses reached to 104, thus raising the response rate close to 58 per cent.

A focus group discussion was also conducted after the survey. The participants included seven faculty members from Kuwait University and Public Authority for Training and Education. Results from the survey were distributed to the participants of the focus group discussion. They were also given a copy of lead questions related to the need for a $\mathrm{PhD}$ program (including the needs of implementing it in Kuwait, career opportunities and who would benefit from it), the proposed structure (including the duration, format, component and registration type), and the proposed course contents (including the areas of specialization). Information from the focus group discussion were from a broader perspective, particularly in terms of professional implications and job market. Comments from the focus discussion have been integrated in the finding to discuss results.

Procedures used for gathering needs assessment data are in line with the best practices for developing doctoral programs in different disciplines. Edwards reported that a web-based survey was used to seek opinions concerning current and future educational needs, as well as for the need for graduate level education programs [19]. Methods used to collect data to explore the need for a $\mathrm{PhD}$ program in Public Administration at Texas State University included document analysis, website analysis, survey research, and interviews with key stakeholders [20]. Cancis and Canc isused a quantitative-based needs assessment procedure with convenient sampling to establish the needs of graduate studies at a university in Turkey [21].

\section{Findings}

\subsection{Participant Profile}

The majority of the participants were former graduates of the department of information studies who were aspiring to pursue higher education in the field of information studies. Questionnaires were also sent to information professionals who were not graduates of Kuwait University. Table 1 demonstrates the participants profile where $80 \%$ of 104 respondents, had Master's degrees with specializations in humanities and social sciences. Respondents with specializa- 
tions in science $\&$ technology, and business were $62,21,14$ percent respectively. The participants were working in schools, health sector, ICT organizations, universities and other public and private organizations. More than $30 \%$ of them were from academic and research institutions and $28 \%$ worked in public domain agencies. About $70 \%$ were 37 years or younger, $48 \%$ had work experience of 7 years or less whereas $19 \%$ had work experience of 13 year or longer.

\subsection{Interest in Enrollment in PhD Program}

Table 2 shows participant responses about enrollment possibilities if a $\mathrm{PhD}$ is introduced in Kuwait University. Quite significantly, $87 \%$ of the participants were keen in seeking admission in the program while $64.7 \%$ would recommend admission to other colleagues. Also $45.7 \%$ noted that students from the other GCC countries (Bahrain, Oman, United Arab Emirates, Qatar, and Saudi Arabia) might be interested to enroll in the program. About every third participant reported that the program might attract students from outside the region.

Rehman quoted an example from Southeast Asia about enrollment in $\mathrm{PhD}$ program of the Nanyag Technological University (NTU) of Singapore [22]. NTU selects students in. its $\mathrm{PhD}$ program from many neighboring or regional countries. Some regions are like one unit in geographic, linguistic and cultural aspects and any program of doctoral studies may serve the needs of its region. In case of Kuwait, regional cooperation has better chances of success due to proximity of language and culture.

Table 1. Participant profile.

\begin{tabular}{ccc}
\hline Education: & Master/PhD & $80 \%$ \\
Specialization: & Bachelor/Graduate student & $20 \%$ \\
& Humanities \& Social Sciences & $62 \%$ \\
& Science \& Technology & $21 \%$ \\
Institution affiliated with: & Business & $14 \%$ \\
Age: & Academic \& Research institutions & $38 \%$ \\
& Public Domain Agencies & $28 \%$ \\
Experience: & 37 years and below & $70 \%$ \\
\hline
\end{tabular}

Table 2. Interest in program [ $\mathrm{N}=104]$.

\begin{tabular}{ccc}
\hline Statements & Frequency & Percentage \\
\hline $\begin{array}{c}\text { I will be interested to enroll in the program. } \\
\text { I will recommend the program to other colleagues. }\end{array}$ & 92 & $87.6 \%$ \\
$\begin{array}{c}\text { Professionals from GCC countries } \\
\text { will be interested in the program. }\end{array}$ & 48 & $45.7 \%$ \\
$\begin{array}{c}\text { Other Kuwaiti professionals will be interested in the program. } \\
\text { PhD program may be of interest to } \\
\text { professionals from countries outside GCC. }\end{array}$ & 39 & $37.1 \%$ \\
\end{tabular}


Two Saudi Arabian universities have introduced PhD programs, but these programs, by and large, have been inactive and dormant. Since these are research-based, these do not have the distinct features of coursework, seminars, and preparation of prospective teachers. It was a widely expressed view that the $\mathrm{PhD}$ degree should attract applicants from the GCC and other neighboring Arab nations. Kuwait University aspires to become an academic leader in the Arab world.

In [23] Smith et al. alerted about the attrition of students in doctoral programs. They pointed out several organizational and personal factors that contribute to the number of students leaving $\mathrm{PhD}$ programs after enrollment. The study suggested intervention and program modification to reduce the attrition.

Production of doctorate graduates was important for new knowledge economy as reported in [24]. They thought there was a vital need to look into ways to boost admission and production of doctoral graduates. This study examined the underlying determinants for the choice of pursuing a doctoral degree in Malaysia. They reported that contributing factors to attract individuals into the doctorate program were opportunity, personal attributes, working relevant knowledge, financial support, program structures, and social support.

\subsection{Perception about Career Opportunities}

The participants were asked to give their views about career opportunities after graduation. Table 3 displays frequencies and percentages for different perceptions. More than $80 \%$ of them observed that the degree would broaden their intellectual horizon and opportunities for an academic career. About 70\% considered that it would enhance research capabilities of graduates. About half of them viewed it would enhance their social status. Approximately half of the participants considered $\mathrm{PhD}$ valuable for obtaining senior management positions.

Focus group discussion participants were concerned about the lack of teaching and research jobs for doctoral graduates from Kuwait University. They emphasized that further studies need to be done to make sure that there are ample opportunities available for working professionals after completing $\mathrm{PhD}$ in information studies.

It was a considered view that the utilization of doctoral studies needs to be seen beyond Kuwait and also it should not be restricted to teaching and research positions. The focus group discussants expressed that a quick review of policy statements is needed about the scope of doctoral studies for a wider coverage.

Syracuse University states that graduates develop skills in leading classes, participate in academic service, and pursue independent scholarship

(https://ischool.syr.edu/people/phd-students-on-the-job-market/). University of Maryland considers doctoral studies crucial to professional success and life-long learning. Given the diverse and complex information landscape, students with wide-ranging interests or interdisciplinary experience are well served by the iSchool PhD program (https://ischool.umd.edu/phd-careers). 
Table 3. Career opportunities [ $\mathrm{N}=104]$.

\begin{tabular}{ccc}
\hline Statements & Frequency & Percentage \\
\hline $\begin{array}{c}\text { It will open avenues of teaching career } \\
\text { for information professionals. }\end{array}$ & 86 & $81.9 \%$ \\
$\begin{array}{c}\text { It will upgrade intellectual level of working professionals. } \\
\text { It will improve research capabilities }\end{array}$ & 85 & $80.9 \%$ \\
of practicing information professionals. & 73 & $69.5 \%$ \\
It will enhance sense of accomplishment. & 62 & $59.0 \%$ \\
It will enhance social status. & 56 & $53.3 \%$ \\
It will prepare for professional development programs. & 52 & $49.5 \%$ \\
It will help in getting senior administrative positions. & 49 & $46.6 \%$ \\
\hline
\end{tabular}

Rehman reported that librarians would like to pursue $\mathrm{PhD}$ because of personal, professional, and academic reasons. These include better job, personal fulfillment, higher salaries, and social prestige [22]. Librarians wish to pursue doctoral studies for academic reasons including conducting research, adding to body of knowledge, teaching and supervising graduate studies, belonging to academic fraternity, and seeking higher academic positions.

Hiring degree holdets of $\mathrm{PhD}$ is affected by several factors. Basil \& Basil stated that institutions and candidates do not have similar conditions [25]. Hiring institutions differ in whether they seek teaching or research ability and this is expected if the institution grants $\mathrm{PhD}$. Candidates are also looking for something different-work environment, lifestyle, or research support.

\subsection{Pedagogical Features}

We sought participant input about the desirable pedagogical features of the program. Table 3 shows distribution of their views. About $84 \%$ considered a combination of coursework and research and admission for both full- and part-time students. About half of them favored the options of online courses and conduct of research at employment venues. About one-third of them noted the need of major and minor as specialization and provision of either as an external or a resident scholar. About one-fourth endorsed an external examination.

We also gathered participant perceptions about length of duration of the proposed PhD program. Opinion was evenly split for the two options of 3 years or 3 - 4 years. Only seven participants thought that the duration should be 5 years. Table 4 displays these results.

Focus group discussion participants concurred with the views of survey participants. There appears to be a consensus that the doctoral program in information studies in Kuwait University should follow a combination of course work and research. It should be offered both full-time and part-time and should employ both face-to-face and online course delivery. There is also a concurrence about the duration of the program of 3 - 5 years. 
Table 4. Pedagogical features [ $\mathrm{N}=104]$.

\begin{tabular}{ccc}
\hline Statements & Frequency & Percentage \\
\hline Combining coursework and research component & 88 & $83.8 \%$ \\
Registering as full-time or part-time student & 88 & $83.8 \%$ \\
Taking some courses in online format & 56 & $53.3 \%$ \\
Completing thesis research at the employing organization & 49 & $46.6 \%$ \\
Completing some courses in other universities & 40 & $38.1 \%$ \\
Having two areas of study as major and minor & 40 & $38.1 \%$ \\
Joining as a resident or external student & 37 & $35.2 \%$ \\
Managing external examination & 28 & $26.6 \%$ \\
\hline
\end{tabular}

\subsection{Areas of Specialization}

It was significant to seek participant input about their intended areas of specialization. Table 5 shows perceptions about different possibilities. Three areas, topping the list in the range of $71 \%-77 \%$, were related to information technology applications, information and knowledge management, and management. It is interesting to note that $65 \%$ of the participants still consider the area of library and information science as an important specialization of the field of information studies. Sixty-three percent chose the area of information behavior as a major specialization. Only $20 \%-30 \%$ found legal informatics, health informatics and archives and records as their choices at the bottom.

Areas of specialization, preferred by participants, reflect the latest trends in the field of information studies. Popular doctoral programs in reputable universities also include these areas of specializations in their $\mathrm{PhD}$ programs. Focus group discussion participants also concurred with the opinions of the survey participants.

McGill University in Canada emphasizes that students develop scholarly and innovative expertise in the broad research area of human-information interaction and the core research areas, information behavior \& services, and information \& knowledge management. Students begin with a set of common core courses and proceed to specialization through advanced course work and dissertation topic, focused on areas of expertise and supported by research interests of the faculty members. https://www.mcgill.ca/sis/programs/phd.

Nanyang Technological University of Singapore focuses on the following areas in Phd of Information Studies: Human computer interaction, games and gamification, information retrieval and analytics, social media, mobile and ubiquitous computing, information behaviour, information literacy, knowledge organization, knowledge management applications and practices.

http://www.wkwsci.ntu.edu.sg/programmes/ProspectiveStudents/Prospective \%20Masters\%20and\%20PhD\%20students/Programmes\%20by\%20Research/Doc tor\%20of\%20Philosophy/Pages/Home.aspx

About half of the participants preferred 18 - 21 credit hour coursework; another $37 \%$ favored $24-27$ credit hours and only $18 \%$ considered the choice of 
30 - 36 credit hours. Participants of focus group discussion also agreed with the input from survey participants. Credit hour course requirement vary in overseas universities.

\subsection{Coursework Area}

In Table 6, the participants identified areas of coursework they considered viable for the PhD program. Five areas, topping the list, identified by $77 \%, 72 \%$, $71 \%, 69 \%$, and $68 \%$, were respectively related to information and knowledge applications, advances in information studies, information technology applications, knowledge organization, and research methods. Apparently, uniformity prevails about the significance and relevance of these courses. Management and statistics course were the two last areas, each identified by $46 \%$ and $40 \%$.

As shown in Table 6, participants considered information and knowledge management and information technology applications as the main focus of doctoral studies. It also reflected the latest trends and the focus of the discipline of information studies. Focus group discussion participants agreed with the input from survey participants. In Kuwaiti context, they recommended to add archives and records management in the focus areas for doctoral studies. Focus group discussion participants also recommended to have seminar courses in major focus areas of information studies.

Table 5. Areas of specialization [ $\mathrm{N}=104]$.

\begin{tabular}{ccc}
\hline Statements & Responses & Percentage \\
\hline Information Technology Applications & 81 & $77.8 \%$ \\
Information and Knowledge Management & 79 & $75.9 \%$ \\
Managing Information Organizations & 74 & $71.1 \%$ \\
Library and Information Science & 65 & $62.5 \%$ \\
Information Behavior & 63 & $60.5 \%$ \\
Business Informatics & 40 & $38.4 \%$ \\
Archives and Records & 31 & $29.8 \%$ \\
Health Informatics & 26 & $25 \%$ \\
Legal Informatics & 21 & $20.1 \%$ \\
\hline
\end{tabular}

Table 6. Coursework areas $[\mathrm{N}=104]$.

\begin{tabular}{ccc}
\hline Statements & Responses & Percentage \\
\hline Information and Knowledge Management & 81 & $77.1 \%$ \\
Advances in Information Studies & 76 & $72.3 \%$ \\
Information Technology Applications & 76 & $72.3 \%$ \\
Knowledge Organization & 73 & $69.5 \%$ \\
Research Methods & 72 & $68.5 \%$ \\
Management Practices & 49 & $46.6 \%$ \\
Statistics & 42 & $40 \%$ \\
\hline
\end{tabular}


A modular approach to $\mathrm{PhD}$ in the field of information studies was described by Druin et al. [26] suggesting to embrace the unique interdisciplinarity and multi-disciplinary nature of the field. They highlighted a combination of conceptual and content modules as a way to conceive new approach to doctoral education that foster students' ability to conduct research in their areas of research.

University of Maryland places emphasis on a range of research courses, two foundational doctoral seminars, and electives chosen by the students and their faculty mentors provide both the structure necessary for individuals to become successful researchers and the flexibility that allows them to pursue the research areas about which they are most passionate. https://ischool.umd.edu/phd.

\subsection{Resources in the Department}

The participants also identified those resources they perceived important for the parent department. Table 7 shows the results. Seventy percent of the participants marked the significance of faculty and provision of research and teaching opportunities for scholars. Also $67 \%$ of the respondents marked the statement of support from university management.

Five elements received similar focus and had the percentages of $67 \%, 61 \%$, $58 \%, 58 \%, 57 \%$, and $54 \%$. These elements were related to library resources, experience in managing graduate studies, experience in academic leadership, engaging visiting professors, and faculty's international exposure to research and publication, Forty percent marked the need of adequate physical facilities in the college.

As shown in Table 7, participants appear to be convinced that the Department of Information Studies has adequate qualified faculty to run the doctoral program. Focus group discussion participants, however, expressed concerns about the adequacy of library and information resources.

\subsection{Desirable Collaboration}

The participants' views about possible collaboration with internal or external choices are presented in Table 8 . It was found that $82.8 \%$ favored on-campus collaboration with other departments. Sixty of them (57.1\%) marked alliances with external industries. Many of them preferred collaborating with other universities. Fifty-eight (55.2\%) marked the choice of collaborating with external examiners.

As shown in Table 8, survey participants considered collaboration with other academic departments very important in the success of the doctoral program. There appears to be a consensus among the focus group discussion participants about the existing thinking about multi-disciplinary collaborations in the university. It is however encouraging to have the name of the program and the department to be changed to information studies. This is an indication of interdisciplinarity in the field. It is in line with the international trends. Nelson reported 
that structure of $\mathrm{PhD}$ programs could be affected as a result of collaboration between academia and industry [27]. Such collaborations are becoming more successful in the changing landscape of education.

Collaboration may have different forms. Universities encourage collaboration in doctoral studies by allowing students take courses outside their parent department. For example, at City University of New York, the Graduate Center offers a number of interdisciplinary concentrations which encourage students to find courses across different academic disciplines.

https://www.gc.cuny.edu/Degrees-Research/Doctoral-Programs/Collaborative -and-Interdisciplinary-Programs

Strategic partnerships can also be initiated with other universities for joint supervision of research and with anchor information industries to carry out practical research projects. Universities also collaborate, with research organizations in seminars. For example, at McGill University, research seminars are presented by Canadian and international guest speakers throughout the year. The series offers a valuable opportunity for $\mathrm{PhD}$ students to learn about current research topics and developments in the field of information studies.

https://www.mcgill.ca/sis/programs/phd.

\subsection{Incentives for Students}

Table 9 presents four incentives that might attract students. Eighty-one percent preferred the provision of financial assistance. Sixty-eight percent noted the needs for the award of research grant from KFAS. On the lower end, 44 and 38 percent of the participants noted the need for leave of absence and university stipend. Since Kuwaiti public sector employers have a generous policy for study leave and the university has the established practice for the award of scholarship, respondents may have treated them for granted provisions.

Table 7. Needed resources $[\mathrm{N}=104]$.

\begin{tabular}{ccc}
\hline Statements & Responses & Percentage \\
\hline $\begin{array}{c}\text { Adequate number of qualified faculty members } \\
\text { Opportunities for graduates to } \\
\text { assist in teaching and research }\end{array}$ & 73 & $69.5 \%$ \\
Support from the university management & 73 & $69.5 \%$ \\
Access to relevant information resources in the library & 71 & $67.6 \%$ \\
Eunning graduate studies in LIS & 65 & $61.9 \%$ \\
Experience in academic leadership & 61 & $58.1 \%$ \\
Possibility of inviting visiting experts & 61 & $58.1 \%$ \\
International exposure of faculty in research and publications & 60 & $57.1 \%$ \\
Availability of adequate physical & 57 & $54.2 \%$ \\
facilities in the college of social sciences & 42 & $40 \% \mid$
\end{tabular}


Table 8. Desirable collaborations [N = 104].

\begin{tabular}{ccc}
\hline Statements & Responses & Percentage \\
\hline $\begin{array}{c}\text { Partnership with other academic departments in the university } \\
\text { Alliances with industries and information } \\
\text { institutions to strengthen research component }\end{array}$ & 87 & $82.8 \%$ \\
$\quad \begin{array}{c}\text { Arrangement with other universities } \\
\text { in the region to allow external students to take courses } \\
\quad \begin{array}{l}\text { Invite international experts for research } \\
\text { collaboration as external examiners }\end{array}\end{array}$ & 60 & $57.1 \%$ \\
\hline
\end{tabular}

Table 9. Desirable incentives [ $\mathrm{N}=104]$.

\begin{tabular}{ccc}
\hline Statements & Responses & Percentage \\
\hline Financial assistance in the form of teaching/research assistantships & 85 & $80.9 \%$ \\
Research grants for PhD scholars from KFAS & 72 & $68.5 \%$ \\
Leave of absence with salary & 47 & $44.7 \%$ \\
University stipend & 40 & $38.1 \%$ \\
\hline
\end{tabular}

The strongest area in favor of $\mathrm{PhD}$ studies at Kuwait University is the incentives for applicants for $\mathrm{PhD}$ in information studies. The current university policies are sympathetic and favorable for students. Focus group discussion participants pointed out further possible opportunities through sponsorships from KFAS.

Cookestated that the doctoral process is a difficult one. She pointed out that it is more complicated when considering minority doctoral students [28]. Nonetheless, it is a vital, transformative, and worthwhile process that more librarians, particularly those from underrepresented backgrounds, should seriously consider. Even though her comments are with regard to diversity in $\mathrm{PhD}$ programs in the US most of the factors she mentioned will be applicable to doctoral candidates in the GCC region.

Most reputable doctoral programs offer generous financial support to $\mathrm{PhD}$ students. College of Information Studies at University Maryland announces "We guarantee funding for all admitted full-time students. We also encourage part-time students working in areas that complement their doctoral research." https://ischool.umd.edu/phd.

\section{Conclusions and Implications}

Doctoral programs are important for the maturity of information studies as an academic discipline. These are also crucial for building scholastic and research capabilities in senior information professionals particularly those holding higher management positions. Introducing a doctoral program is an important undertaking that requires commitment of substantial resources on the part of the academic institution. It is also a big commitment on part of those who intend to enroll in a doctoral program in terms of opportunity cost and hard work re- 
quired to complete the $\mathrm{PhD}$ degree. It is therefore important that input is sought from all stakeholders in the process of development of doctoral degrees.

This study was conducted to understand the insights of stakeholders of a PhD program in information studies in a university in the Arabian Gulf Region. There was a great deal of diversity among the participants of the survey in their areas of study, professional positions, and institutional affiliation. It is reliably premised that the insights of this group are overwhelmingly reassuring. Most participants expressed interest in pursuing a doctoral degree. They perceived that a $\mathrm{PhD}$ program will provide them an opportunity to advance their career in research, teaching, senior management, and consulting. Initiation of doctoral program appeared to be popular as expressed by information professionals in the needs assessment study. Faculty who participated in the focus group discussion were quite confident that a doctoral program in information studies at $\mathrm{Ku}$ wait University will attract applicants from the other Arabian Gulf countries. Needs assessment exercise was reinforcing for the Department of Information Studies as the survey clearly showed a need for starting a $\mathrm{PhD}$ program.

The input of the respondents provided information that was helpful in the design of the structure of the proposed program, its content, areas of coursework and specializations. Stakeholder input through questionnaire and focus group discussion indicated that an interdisciplinary degree will be more appropriate considering the job market and potential pool of participants. Stakeholders' insights also suggested focusing on theoretical and applied research and the program to be run with flexibility and diversity in delivery options to provide opportunities to a wide range of professionals.

Suggestions were made on inclusion of advanced information studies course to provide foundation to enhance intellectual and scholarly abilities of doctoral candidates. Most participants thought that doctoral studies with strong theoretical orientation will help produce intellectual, inquisitive, and enlightened leadership for national and regional leadership roles in the spheres of information and knowledge. Doctoral studies will also help prepare professionals for higher-level positions in research, teaching, and practice in the area of information. $\mathrm{PhD}$ graduates will contribute to research and scholarship in the broad field of information and knowledge management.

This study is not without limitations. As data were only collected from the GCC region. The context and process imposed constraints on this sample size; however results of this study provide useful guidelines for conducting needs assessment for doctoral programs in information studies. This study was helpful in exploring the future needs for a doctoral program that collected information from working information professionals. Future studies may also include prospective employers including the academic administrators and top management in anchor information industries: libraries and information centers, archives and records management departments, and the corporate sector. Findings also provide useful information that can be used for initial outline for program structure and course content for parties interested in initiating a proposal for developing a 
doctoral program. The methodology used in this exercise will also be helpful to those interested in conducting feasibility for $\mathrm{PhD}$ program in a university.

\section{Conflicts of Interest}

The authors declare no conflicts of interest regarding the publication of this paper.

\section{References}

[1] Robbins-Carter, J. and Seavey, C.A. (1986) The Master's Degree: Basic Preparation for Professional Practice. Library Trends, 34, 561-580.

[2] Williamson, C.C. (1923) Training for Library Service: A Report Prepared for the Carnegie Corporation of New York. Carnegie Corp., New York.

[3] Bobinski, G.S. (1986) Doctoral Programs in Library and Information Science in the United States and Canada. Library Trends, 697-714. https://core.ac.uk/download/pdf/4816780.pdf

[4] Hayes, R.M. (1986) Accreditation. Library Trends, 34, 537-559.

[5] Rehman, S. (2000) Preparing the Information Professional: An Agenda for the Future. Greenwood Publishing, Westport.

[6] Paris, M. (1991) Library School Closings: The Need for Action. The Library Quarterly, 61, 259-262.

[7] Saracevic, T. (1994) Closing of Library Schools in North America: What Role Accreditation? Libri, 44, 190-200.

[8] Mokros, H.B. (2008) One iSchool's Ideas and Identity: Doctoral Research and Training at Rutger's-SCILS 1959-2007. https://www.ideals.illinois.edu/handle/2142/15071

[9] Jaeger, P.T., Golbeck, J., Druin, A. and Fleischmann, K.R. (2010) The First Workshop on the Future of iSchool Doctoral Education: Issues, Challenges, and Aspirations. Journal of Education for Library and Information Science, 51, 201-208.

[10] Powell, R.R., Baker, L.M. and Mika, J.J. (2002) Library and Information Science Practitioners and Research. Library \& Information Science Research, 24, 49-72.

[11] Fleming-May, R. and Yuro, L. (2009) From Student to Scholar: The Academic Library and Social Sciences PhD Students' Transformation. Portal: Libraries and the Academy, 9, 199-221.

[12] Kniffel, L. (2009) Illinois's Dominican University Establishes LIS PhD Program. American Libraries, 40, 21.

[13] Sugimoto, C.R. (2012) Initiation, Cultivation, Separation and Redefinition: Application of Kram's Mentoring Framework to Doctoral Education in Information and Library Science. Journal of Education for Library and Information Science, 53 98-114

[14] Bennett-Kapusniak, R., Glover, J., McCleer, A., Thiele, J. and Wolfram, D. (2016) Planning LIS Doctoral Education around a Focused Theme: A Report on the B2A Program. Journal of Education for Library and Information Science, 57, 69-78.

[15] Servage, L. (2009) Alternative and Professional Doctoral Programs: What Is Driving the Demand? Studies in Higher Education, 34, 765-779.

[16] Garcia-Quevedo, J., Mas-Verdú, F. and Polo-Otero, J. (2012) Which Firms Want PhDs? An Analysis of the Determinants of the Demand. Higher Education, 63, 
607-620.

[17] Gokhberg, L., Meissner, D. and Shmatko, N. (2017) Myths and Realities of Highly Qualified Labor and What It Means for PhDs. Journal of the Knowledge Economy, 8, 758-767.

[18] Grimm, K. (2018) Assessing the Industrial PhD: Stakeholder Insights. Journal of Technology and Science Education, 8, 214-230.

[19] Edwards, M.L. (2003) A Web-Based Assessment for the Need to Develop Graduate Degree Programs in Prosthetics and Orthotics. Thesis for Master's of Health Professions Education in the Graduate College of the University of Illinois, Chicago.

[20] Valera, G. (2007) A Needs Assessment for a Ph.D. Program in Public Administration for Texas State University. An Applied Research Project (Political Science 5397), Department of Political Science Texas State University.

[21] Cansiz, M. and Cansiz, N. (2015) A Needs Assessment for Graduate Programs in Education Faculties. Journal of Educational and Instructional Studies in the World, 5, 2146-7463.

[22] Rehman, S. (2018) Doctoral Studies: Development and Design. In: Chaudhry, A.S., Rehman, S. and Majid, S., Eds., Information Education: Imperative of the Digital Environment, Noor Publishing, Saarbrücken, 280 p.

[23] Smith, R.L., Maroney, K., Nelson, K.W., Abel, A.L. and Abel, H.S. (2006) Doctoral Programs: Changing High Rates of Attrition. The Journal of Humanistic Counseling, 45, 17.

[24] Ng, S.F., Muhd, N.M.N., AbRahman, K. and Ismail, N. (2011) Influential Factors to Pursue Doctorate Degree in Malaysia. Procedia-Social and Behavioral Sciences, 15, 2028-2032.

[25] Basil, M.D. and Basil, D.Z. (2006) The Marketing Market: A Study of PhD Supply, Demand, Hiring Institutions, and Job Candidates. Journal of Business Research, 59, 516-523.

[26] Druin, A., Jaeger, P.T., Golbeck, J., Fleischmann, K.R., Lin, J., Qu, Y., Xie, B., et al. (2009) The Maryland Modular Method: An Approach to Doctoral Education in Information Studies. Journal of Education for Library and Information Science, 293-301.

[27] Nelson, K. (2014) Challenges and Opportunities for PhD's: Expectations of Employment in Non-Academic or Non-Tenure Environments. Aaua, 29, 68-77.

[28] Cooke, N.A. (2014) The Spectrum Doctoral Fellowship Program: Enhancing the LIS Professoriate. InterActions: UCLA Journal of Education and Information Studies, 10. https://escholarship.org/uc/item/7vb7v4p8 